\title{
Pemberian Jus Tomat (Lycopersicum esculentum) Per Oral Dapat Menurunkan Jumlah Sel Epitel Bronkhus Utama Tikus Putih yang Dipapar Asap Rokok Sub Kronik
}

\section{Tomatoes Juice Reduce Bronchus Epithelial Cell in Rat with Sub Chronic Exposed to Cigarette Smoke}

\author{
Mudjiwijono Handaru $E^{1}$, Nunuk Sri $M^{2}$, Indah Srini $N k^{3}$ \\ ${ }^{1}$ Laboratorium Patologi Anatomi Fakultas Kedokteran Universitas Brawijaya Malang \\ ${ }^{2}$ Laboratorium IImu Penyakit Paru Fakultas Kedokteran Universitas Brawijaya Malang \\ ${ }^{3}$ Program Studi Pendidikan Dokter Fakultas Kedokteran Universitas Brawijaya Malang
}

\begin{abstract}
ABSTRAK
Asap rokok mengandung radikal bebas yang dapat dipercaya dapat meningkatkan sel epitel bronkhus. Tujuan Penelitian ini dilakukan untuk mengidentifikasi efek jus tomat yang mengandung likopen dalam menurunkan sel epitel bronkhus akibat stres oksidatif yang di sebabkan paparan asap subkronik pada tikus. Penelitian dilakukan dengan desain eksperimental pada 20 tikus jantan usia 2-3 bulan dengan berat badan 150-200 gram dan di kelompokkan dalam kelompok kontrol positif dan negatif juga tiga kelompok perlakuan dengan pemberian jus tomat $1.15 \mathrm{ml} / \mathrm{hari}, 2.3 \mathrm{ml} / \mathrm{hari}$, dan $4.6 \mathrm{ml} /$ hari. Uji One-Way ANOVA dan Post hoc LSD menunjukkan bahwa peningkatan intake jus tomat menurunkan jumlah sel epitel bronkus secara signifikan hingga sama dengan kondisi normal.
\end{abstract}

Kata Kunci : Jus tomat, likopen, paparan asap rokok sub kronis, sel epitel bronkus.

ABSTRACT

Cigarette smoke contains free radicals which are believed lead to increase the total amount of bronchus epithelial cells. This research aimed to identify the effect of tomatoes juice containing lycopene in increasing the amount of bronchus epithelial cells of subchronic cigarette smoke exposed rat. True experimental design was applied on 20 male wistar rat age 2-3 months, 150-200 gram in weight. The samples were randomly divided into positive and negative control groups as well as three treatment groups administered with tomatoes juice 1,15 ml/days, 2,3 ml/days, and 4,6 $\mathrm{ml} /$ days dosages. Oneway ANOVA test and post hoc LSD show that tomatoes juice intake significantly decrease the total amount of bronchus epithelial cells equal to to the normal condition. The higher the tomatoes juice dosage, the lower the total amount of epithelial cells of bronchus $(r-0,809, p<0,001)$.

Keywords : Bronchus epithelial cells, lycopene, tomatoes juice, sub chronic cigarette cells exposure

Jurnal Kedokteran Brawijaya, Vol. 26, No. 1, Februari 2010; Korespondensi: Mudjiwijono Handaru E. Laboratorium Patalogi Anatomi Fakultas Kedokteran Universitas Brawijaya Malang, Jl. Veteran Malang Tel. (0341)569117 Email:pa_fkub@yahoo,com 


\section{PENDAHULUAN}

World Health Organization (WHO) menyebutkan bahwa rokok merupakan salah satu ancaman terbesar terhadap kesehatan masyarakat pada abad ke 21 . Setiap tahunnya 5 juta orang didunia meninggal akibat merokok, bahkan pada tahun 2030 diperkirakan mencapai 10 juta orang per tahun. Menurut laporan Depkes RI, sedikitnya 9\% dari 3.320 kematian pada tahun 2001 diakibatkan merokok. Merokok telah terbukti berkaitan dengan sedikitnya 25 jenis penyakit, dengan kematian terbesar adalah karena kanker paru (87\%) dan bronkhitis kronik (82\%) (1).

Rokok menghasilkan lebih dari 4000 bahan hasil pembakaran dan ratusan diantaranya adalah bahan aditif. Dalam setiap hisapan, terdapat $10^{14}$ radikal bebas dan dapat dipertahankan dalam waktu yang relatif lama ( $>10$ menit) (2). Meningkatnya proliferasi epitel jalan napas akibat paparan asap rokok merupakan salah satu mekanisme penting terjadinya penyakit paru obstruktif pada perokok. Studi morphometric yang dilakukan oleh Miller et al menemukan adanya hubungan yang kuat antara ketebalan epitel jalan napas dan obstruksi jalan napas(3). Hiperplasi sel epitel merupakan konsekuensi proses inflamasi yang berhubungan dengan mekanisme perlindungan untuk mengatasi pathogen dari luar tubuh(4).

Hiperplasia atau peningkatan jumlah sel epitel bronkhus akibat stress oksidatif yang diinduksi oleh asap rokok disebabkan oleh aktivasi dari Epidermal Growth Factor Receptor (EGFR). Reseptor ini terlibat dalam berbagai macam proses biologi termasuk diantaranya proliferasi dan diferensiasi sel (5). Aktivasi EFGR akan mencegah apoptosis sel bersilia dan mengirim sinyal pada IL-13 untuk mendiferensiasi sel-sel bersilia menjadi sel goblet (4). Selain itu, aktivasi dari EFGR akan menginduksi gen MUC5AC yang menyebabkan sintesis mukus dan hiperplasi sel goblet pada tikus secara invivo (6).

Langkah yang paling tepat untuk menghadapi serangan radikal bebas adalah dengan mengurangi paparan atau mengoptimalkan pertahanan tubuh melalui aktivitas antioksidan. Kecenderungan masyarakat saat ini adalah memilih mengonsumsi bahan-bahan yang alami karena diyakini lebih aman dari kemungkinan efek samping. Sumber antioksidan alami sangatlah beragam, diantaranya didapatkan pada buah dan sayur yang banyak mengandung vitamin $A, C$ dan $E$ sebagai antioksidan termasuk tomat.

Tomat mengandung vitamin C (160-240 mg/kg), provitamin A karoten $(6-9 \mathrm{mg} / \mathrm{kg}$ ) dan komponen phenolic flavonoids (5-50 mg/kg) dan phenolic acids $(10-50 \mathrm{mg} / \mathrm{kg})$. Selain itu juga terdapat sedikit vitamin $\mathrm{E}(5-20 \mathrm{mg} / \mathrm{kg})$, dan trace element copper $(0,1-0,9 \mathrm{mg} / \mathrm{kg})$ manganese (1-1,5 $\mathrm{mg} / \mathrm{kg}$ ) dan zinc $(1-2,4 \mathrm{mg} / \mathrm{kg})$. Tomat dikenal sebagai sumber utama likopen. Likopen termasuk senyawa karotenoid yang memberikan warna merah pada tomat. Telah dibuktikan secara in vitro bahwa likopen merupakan penangkal radikal bebas yang paling efektif diantara karotenoid yang lain, termasuk $\beta$-caroten(7). Diduga tomat mampu mengurangi stres oksidatif yang terjadi akibat paparan asap rokok sehingga dapat mempengaruhi jumlah sel epitel bronkhus setelah dipapar dengan asap rokok sub kronik. Selain itu di Indonesia, buah tomat mudah ditemui dan harganya relatif murah. Penelitian ini dilakukan untuk membuktikan efek pemberian jus tomat per oral terhadap jumlah sel epitel bronkhus utama tikus Wistar setelan dipapar asap tokok sub kronik

\section{METODE}

Penelitian dilakukan dengan metode eksperimental laboratorik in vivo dengan desain post-test-only with control. Rancangan percobaan yang digunakan adalah rancangan acak lengkap dengan pengkondisian paparan asap rokok sub kronik dan perlakuan pemberian jus tomat dalam tiga dosis. Pada penelitian ini, hewan coba tikus putih Rattus norvegicus Strain Wistar yang didapatkan dari Laboratorium Farmakologi Fakultas Kedokteran Brawijaya dibagi menjadi 5 kelompok yaitu 1 kelompok kontrol positif dan negatif serta 3 kelompok perlakuan secara acak. Kelompok kontrol negatif (K1) tidak mendapatkan paparan asap rokok maupun pemberian jus tomat. Keempat kelompok lain dilakukan pengkondisian dengan paparan asap rokok selama 9 minggu, dengan tiga diantaranya diberikan jus tomat dosis $1.15 \mathrm{ml} /$ hari (K3), $2.3 \mathrm{ml} /$ hari (K4) dan $4.6 \mathrm{ml} /$ hari (K5) selama tiga minggu.

Digunakan 3 macam dosis jus tomat untuk menentukan dosis optimal yang dapat menurunkan jumlah sel epitel yang mengalami peningkatan setelah dipapar asap rokok sub kronik. Penentuan dosis jus tomat berdasarkan studi sebelumnya, yaitu likopen pada dosis $15 \mathrm{mg}$ dan $30 \mathrm{mg}$ yang terdapat pada produk tomat memiliki biovailabilitas tinggi dan efek propektif yang tinggi menangkal stress oksidatif(8). Dosis $1,1 \mathrm{mg} / \mathrm{kgBB} /$ hari pada tikus setara dengan pemberian $15 \mathrm{mg}$ likopen perhari pada manusia (9). Perhitungan dosis jus tomat berdasar pada kadar likopen dalam $240 \mathrm{ml}$ jus tomat adalah 22,9 mg. Jus tomat diberikan per oral menggunakan sonde karena dengan cara ini larutan dapat langsung masuk ke dalam lambung tikus sehingga dosis yang diharapkan dapat tercapai dan perlakuan dapat lebih terkontrol. Jus tomat dibuat dari tomat yang masak berwarna merah diambil sarinya dengan menggunakan juicer. Tomat yang digunakan adalah tomat merah segar yang biasa ada dipasar tradisional (lycopersicum commune) untuk mendapatkan kadar likopen yang tinggi. Pemaparan asap rokok jenis kretek dilakukan dengan menggunakan bantuan alat smoking pump Dosis pemaparan setiap 3 ekor tikus adalah 1 batang rokok per hari selama 9 minggu.

Setelah 12 minggu, dilakukan pengambilan bronchus pada setiap tikus pada kelima kelompok tersebut untuk dibuat sediaan histopatologi dengan pengecatan HematoxylinEosin. Sediaan diamati pada mikroskop pembesaran 400x. Penghitungan jumlah sel dilakukan pada 10 lapang pandang yang dipilih secara acak pada setiap sediaan (10). Perbedaan rata-rata jumlah sel epitel bronkhus utama antara kelompok dianalisis dengan uji One Way Anova dan uji Tukey LSD. Hubungan dosis jus tomat dengan jumlah sel epitel bronkhus utama tikus yang telah terpapar asap rokok sub kronik dianalisis dengan uji korelasi Pearson.

\section{HASIL}

Hasil penelitian menunjukkan penurunan jumlah sel epitel bronkhus sesudah pemberian jus tomat (Gambar 1). Kelompok kontrol positif menunjukkan jumlah sel yang tinggi yang menggambarkan pemaparan asap rokok pada proses penelitian mengakibatkan peningkatan jumlah sel. 
epitel bronkhus dibandingkan normal. Grafik juga menunjukkan semakin besar dosis jus tomat semakin besar penurunan jumlah sel dibandingkan kontrol positif, dan pada dosis ketiga (4.6 ml/hari) menunjukkan jumlah sel epitel hampir sama dengan kondisi normal.

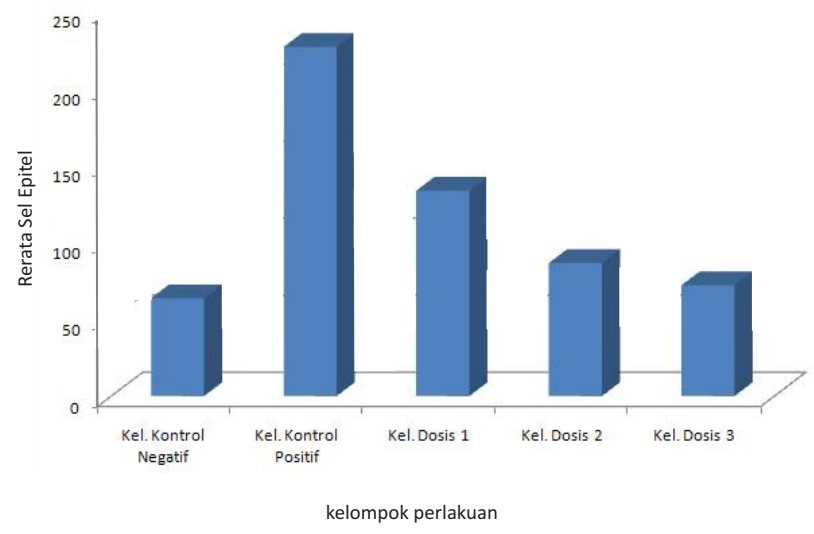

Gambar 1. Grafik rerata jumlah sel epitel bronkus utama

Penurunan jumlah sel epitel sesudah pemberian jus tomat tersebut terbukti signifikan dengan uji One Way Anova $(\rho<0,01)$. Hasil analisis Post Hoc dengan metode $L S D$ (Tabel 1) menunjukkan bahwa kelompok kontrol negatif (K1) berbeda nyata dengan kelompok kontrol positif (K2) dan kelompok K3. Jumlah sel sesudah pemaparan asap rokok berbeda nyata dengan kelompok tanpa pemaparan dan sesudah pemberian jus tomat. Jumlah sel epitel bronkus utama kelompok dengan pemberian dosis $1.15 \mathrm{ml} /$ hari berbeda nyata dengan semua kelompok kecuali dengan kelompok dengan pemberian dosis $2.3 \mathrm{ml} /$ hari, sedangkan kelompok dengan pemberian dosis $2.3 \mathrm{ml} /$ hari hanya berbeda nyata dengan kelompok kontrol positif.

Tabel 1. Hasil post hoc test LSD

\begin{tabular}{lccccc}
\hline & Kontrol & Kontrol & \multicolumn{3}{c}{ Dosis jus tomat } \\
& Negatif & Positif & 1,15 & $\mathbf{2 , 3}$ & 4,6 \\
\hline Kontrol Negatif & - & $0,000^{*}$ & $0,023^{*}$ & 0,420 & 0,764 \\
Kontrol Positif & $0,000^{*}$ & - & $0,004^{*}$ & $0,000^{*}$ & $0,000^{*}$ \\
Jumlah Dosis (1,15) & $0,023^{*}$ & $0,004^{*}$ & - & 0,108 & $0,041^{*}$ \\
Jumlah Dosis (2,3) & 0,420 & $0,000^{*}$ & 0,108 & - & 0,608 \\
Jumlah Dosis (4,6) & 0,764 & $0,000^{*}$ & $0,041^{*}$ & 0,608 & - \\
\hline
\end{tabular}

Hasil uji korelasi Pearson menunjukkan korelasi negatif yang kuat dan signifikan $(r=-0.809, p<0,001)$ antara dosis jus tomat dengan jumlah sel epitel. Nilai tersebut menunjukkan bahwa semakin besar dosis jus tomat akan menyebabkan penurunan jumlah sel epitel bronkus utama yang semakin besar pula.

\section{PEMBAHASAN}

Radikal bebas yang berlebihan dalam tubuh telah dibuktikan dapat menimbulkan berbagai macam penyakit (11). Telah banyak upaya dilakukan untuk mencegah timbulnya penyakit akibat radikal bebas pada tubuh. Salah satu upaya tersebut adalah dengan cara melakukan hambatan terjadinya radikal bebas yang berlebih dalam tubuh oleh antioksidan. Upaya untuk mencegah radikal bebas yang berlebih dalam tubuh dapat dilakukan dengan mengkonsumsi bahan-bahan alami yang mengandung antioksidan alami sehingga dapat memperkuat proteksi antioksidan dalam tubuh(12).

Tomat termasuk salah satu bahan-bahan alami yang banyak mengandung antioksidan, antara lain : vitamin C, karotenoid, flavonoid dan asam fenolat. Selain itu, terdapat sedikit vitamin E dan trace element seperti copper, manganese dan zinc yang terdapat pada berbagai enzim antioksidan. Diantara kandungan antioksidan tersebut, likopen merupakan salah satu antioksidan yang paling poten. Kandungan likopen sendiri paling banyak ditemukan dalam tomat (7). Pada penelitian ini, dilakukan percobaan eksperimental untuk mengetahui efek pemberian jus tomat pada jumlah sel epitel bronkus tikus wistar yang telah dipapar asap rokok sub kronik sebagai induktor timbulnya radikal bebas dalam tubuh tikus wistar.

Pada bronkus utama tikus wistar tanpa paparan asap rokok, didapatkan rerata jumlah sel epitel sebanyak 63,5 $( \pm 21,91)$ yang menggambarkan jumlah sel epitel bronkus tikus normal. Pada kondisi normal sel epitel bronkus tikus tersusun oleh sel goblet dan sel bersilia yang berperan pada mucocilliary clearance, yang merupakan komponen tak terpisahkan dari pertahanan terhadap agen infeksius dan zat toksik yang terhirup pada sistem pernafasan (13).

Pemaparan asap rokok sub kronik kretek selama 9 minggu pada tikus Wistar meningkatkan jumlah sel epitel bronkus utama secara signifikan yang ditunjukkan pada kelompok kontrol positif. Hiperplasi atau peningkatan jumlah sel epitel bronkus akibat stress oksidatif yang diinduksi oleh asap rokok disebabkan oleh aktivasi dari EGFR. Reseptor ini terlibat dalam berbagai macam proses biologi termasuk diantaranya proliferasi dan diferensiasi sel(5). Aktivasi EGFR akan mencegah apoptosis sel bersilia dan mengirim sinyal pada IL-13 untuk mendiferensiasi sel-sel bersilia menjadi sel goblet (4).

Radikal bebas dari asap rokok menyerang membran sel yang terdiri dari komponen lipid dan protein. Komponen lipid akan mengalami peroksidasi dengan cara menarik atom $\mathrm{H}$ dari rantai samping PUFA, menghasilkan radikal karbon. Radikal karbon akan bereaksi dengan oksigen menjadi radikal peroksil, inilah yang menyerang ulang rantai samping PUFA menghasilkan radikal karbon baru dan peroksida lipid. Reaksi ini akan berlangsung terus secara berantai dan berakhir bila bertemu dengan radikal bebas lain atau dengan antioksidan (2). 4-hydroxy-2nonenal (4-HNE), merupakan end product dari peroksidasi lipid juga dapat mengaktifkan EGFR (5).

Aktivitas radikal bebas yang berlebihan akibat paparan asap rokok mengakibatkan stress oksidatif, sehingga kapasitas proteksi antioksidan tertekan. Senyawa aldehid dalam asap rokok, terutama acrolein, asetaldehid maupun formaldehid, dapat menekan GSH (glutathione tereduksi). GSH berperan untuk memproteksi terhadap peroksidasi lipid, mereduksi askorbat teroksidasi yang penting dalam proses regenerasi tokoferol, serta menetralkan 4-HNE. Pada cairan pelapis paru perokok juga didapatkan penurunan aktivitas enzim ferroksidase caeruloplasmin yang berfungsi mengoksidasi $\mathrm{Fe}^{2+}$ menjadi Fe (III) dan memfasilitasi pengangkutan besi ke transferring, sehingga dengan besi tidak mengkatalisa reaksi rantai radikal bebas(2). Iritasi asap rokok akan menyebabkan peningkatan sel-sel radang pada saluran napas. Aktifasi dari neutrofil ini juga dapat meningkatkan pembentukan radikal bebas $(6,14,15)$. 
ROS sendiri juga dapat menimbulkan respon inflamasi baik melalui elangsung maupun hasil dari peroksidasi lipid seperti 4-hydroxy-2-nonenal (4-HNE)(5). Neutrofil yang aktif dapat menginduksi ligand-dependend EGFR (15). Inflamasi lokal pada saluran nafas yang diinisiasi ROS pada asap rokok tetap terjadi walaupun telah berhenti merokok. Terjadinya smoking-independent oxidative stress ini menjelaskan mengapa jumlah sel epitel bronkus utama pada kelompok kontrol positif tetap tinggi walaupun paparan asap rokok telah dihentikan selama 3 minggu (16).

Pemberian jus tomat yang mengandung antioksidan bertujuan untuk mengurangi kondisi stress oksidatif dengan indikator penurunan jumlah sel epitel bronkus. Hasil penelitian menunjukkan bahwa pemberian jus tomat selama 3 minggu menyebabkan penurunan jumlah sel epitel bronkus yang semakin besar dengan meningkatnya dosis. Dosis optimal ditemukan pada pemberian $4.6 \mathrm{ml}$ yang setara dengan dosis likopen $30 \mathrm{mg} / \mathrm{hari}$ pada manusia. Pada dosis tersebut pemberian jus tomat mampu menurunkan jumlah sel epitel hingga sama dengan kondisi normal. Penurunan jumlah sel epitel dapat terjadi karena efek antioksidan dari jus tomat mampu menyeimbangkan peningkatan radikal bebas sehingga mengurangi stress oksidatif dalam tubuh. Kandungan antioksidan yang menonjol dari tomat adalah karotenoid dan vitamin C serta beberapa antioksidan lain yang jumlahnya relative kecil yaitu vitamin $E$, flavonoid dan asam fenolat(7). Berdasarkan fungsinya, karotenoid dan vitamin $C$ dapat digolongkan sebagai antioksidan sekunder yang berperan dalam menangkap radikal bebas serta mencegah terjadinya reaksi berantai sehingga tidak terjadi kerusakan yang lebih besar (17). Diantara berbagai kandungan tomat, likopen adalah antioksidan yang paling dominan dan ditemukan dalam jumlah besar sehingga dikatakan sebagai senyawa utama dari buah tomat (18). Oleh karena itu pemberian jus tomat pada penelitian ini didasarkan pada dosis likopen. Kemampuan likopen dalam meredam oksigen tunggal bebas dua kali lebih baik dari betakaroten dan sepuluh kali lebih baik dari pada alfatokoferol (19). Selain itu karotenoid sebagai molekul yang kaya elektron dapat bereaksi dengan radikal bebas sehingga tercapai kestabilan (7). Pada ketiga dosis jus tomat yang diberikan mengandung likopen dalam batasan dosis rendah. Dikatakan dosis rendah karena dosis likopen yang diberikan setara pemberian likopen $<60 \mathrm{mg} /$ hari pada manusia. Likopen dosis rendah member efek antioksidan yang cukup aman dari efek membahayakan yang justru meningkatkan kondisi stress oksidatif (20). Vitamin C dalam tomat juga cukup tinggi sehingga tomat digolongkan sebagai sumber vitamin $C$ yang sangat baik (17). Secara umum vitamin C merupakan antioksidan yang poten melalui berbagai fungsinya (2).

Pemberian jus tomat dengan dosis sebesar $1,15 \mathrm{ml} /$ hari

\section{DAFTAR PUSTAKA}

1. Fifi. Merokok Membahayakan Kesehatan. (Online). nov.2008.http://202.152.33.84/index.php?option $=$ com content \&view=category\&id=9\&/temid $=10$ [diakses tanggal 10 November 2008].

2. Halliwell B and Gutteridge JMC. Antioxidant Defences In Free Radicals. In: Biology and Medicine 3rd edition. New York: Oxford University Press; 1999. menunjukkan belum cukup memberi efek yang optimal meskipun sudah menunjukkan penurunan bermakna. Keadaan ini bisa disebabkan peningkatan radikal bebas belum cukup terimbangi oleh antioksidan dari jus tomat. Pada penelitian sebelumnya didapatkan bahwa dosis likopen $6,5 \mathrm{mg}-30 \mathrm{mg} / \mathrm{hari}$ pada manusia sudah cukup memiliki bioavailabilitas sebagai proteksi melawan stress oksidatif (10). Hasil komsumsi jus tomat dosis $1,15 \mathrm{ml} /$ hari pada tikus yang setara dengan likopen $7,5 \mathrm{mg} /$ hari pada manusia menunjukkan sudah dapat digunakan mengurangi stress oksidatif walaupun belum cukup optimal.

Hasil uji Post Hoc metode LSD menunjukkan bahwa pemberian jus tomat dosis 4,6 $\mathrm{ml}$ cukup optimal dalam melawan stress oksidatif karena menyebabkan penurunan yang signifikan hingga sama dengan kondisi normal. Dengan pemberian dosis ini diperkirakan antioksidan dalam tubuh telah memenuhi jumlah standar untuk dapat menetralkan radikal bebas dalam tubuh. Efek selanjutnya adalah penurunan lipid peroksida sehingga menghambat hyperplasia.

Perlakuan $2,3 \mathrm{ml}$ dan dosis $4,6 \mathrm{ml}$ atau setara dengan likopen $15 \mathrm{mg} /$ hari hingga $30 \mathrm{mg} /$ hari pada manusia tidak menunjukkan perbedaan bermakna. Hasil yang relatif sama pada kedua dosis ini bisa disebabkan kemampuan yang relatif sama dalam meningkatkan jumlah likopen plasma. Penelitian sebelumnya, mengenai dose response dari efek suplementasi likopen terhadap biomarker stress oksidatif juga menemukan peningkatan plasma likopen yang relatif sama pada dosis likopen $15 \mathrm{mg} /$ hari dan $30 \mathrm{mg} / \mathrm{hari}$ (20). Analisis korelasi menunjukkan semakin tinggi dosis jus tomat maka akan membuat jumlah sel epitel menurun mendekati kondisi normal. Jika didasarkan pada penelitian sebelumnya korelasi negatif ini hanya berlaku pada kandungan likopen dosis rendah yang memberi efek antioksidan (20).

Dosis jus tomat dalam penelitian ini telah disetarakan dengan dosis likopen pada manusia. Meskipun demikian uji efek jangka panjang dan uji klinis sangat penting dilakukan pada manusia. Penelitian ini membuktikan potensi jus tomat sebagai antioksidan dalam memperbaiki hyperplasia sel epitel bronkus utama Pemberian jus tomat sebagai antioksidan dapat menurunkan jumlah sel epitel bronkus utama tikus Wistar yang mengalami peningkatan setelah dipapar asap rokok. Semakin tinggi dosis jus tomat yang diberikan semakin besar penurunan jumlah sel epitel bronkus utama tikus Wistar yang mengalami peningkatan akibat paparan asap rokok sub kronik. Pemberian jus tomat dosis 4,6 $\mathrm{ml} /$ tikus/hari selama 3 minggu memberikan efek optimal pada penurunan jumlah sel epitel bronkus utama hingga sama dengan kondisi normal.

3. Miller YE, Blatcford P, Hyun DS, et al. Bronchial Epithelial Ki-67 Index is Related to Histology, Smoking, and Gender, but Not Lung Canceror Chronic Obstructive Pulmonary Disease. Cancer Epidemiology, Biomarkers \& Prevention. 2007; 16: 2425-2431.

4. Tyner JW, Kim EY, Ide K, et al. Blocking Airway Mucous 
Cell Metaplasia by Inhibiting EGFR Antiapoptosis and II-13 Transdifferentiation Signals. The Journal of Clinical Investigation. 2006; 116(2): 309-321.

5. Liu W, Akhand AA, Kato M, et al. 4-Hydroxynonenal Triggers an Epifermal Growth Factor Receptor-linked Signal Pathway for Growth Inhibition. Journal of Cell Science 1999; 112(Pt 14): 2409-2417.

6. Takeyama K, Jung B, Shim JJ, et al. Activation of Epidermal Growth Factor Receptors is Responsible for Mucin Synthesis induced by Cigarette Smoke. American Journal and of Pshiology-Lung Cellular and Molecular Phsiology. 2001: 280(1); L165-172.

7. Grolier P, Bartholin G, Broers L, et al. Composition of Tomatoes and Tomato Products in Antioxidants. In: "White Book" on the Antioxidants in Tomatoes and Tomato Products. Avignon; 1997; 17-95.

8. Rao AV and Shen H. Effect of Low Dose Lycopene Intake on Lycopene Bioavailability and Oxidative Stress. Nutrition Research. 2008; 27(2): 267-273.

9. Veeramachaneni S, Ausman LM, Choi SW, Rusell RM, and Wang XD. High Dose Lycopene Supplementation Increases Hepatic Cytochrome P4502E1 Protein and Inflammation in Alcohol-Fed Rats 1,2. Journal of Nutrition. 2008; 138(7): 1329-1336.

10. Downing TE, Sporn TA, Bollinger RR, Davis RD, Parker $\mathrm{W}$, and Lin SS. Pulmonary Histopathology in an Experimental Model of Chronic Aspiration is Independent of Acidity. Experimental Biology and Medicine. 2008; 233: 1202-1212.

11. Borg DC. Oxygen Free Radical and Tissue Injury. In: Oxygen Free Radical In Tissue Damage. Boston: Brikhauser; 1993.

12. Chow CK. Vitamin and Related Dietary Antioxidan. In: Trace Element Micronutrient and Free Radical. New Jersey: Human Press; 1991.
13. Page CP, Banner KH, and Spina D. Normal Structural of Airways: Cellular Mechanism in Airways Inflammation. Birkhauser: Basel; 2000; 2-3.

14. Fischer BM and Voynow JA. Neutrophil Elastase Induces MUC54C Gene Expression in Airway Epithelium Via a Pathway Involving Reactive Oxygen Species. American Journal of Respiratory Cell and Molecular Biology. 2002; 26: 447-453.

15. Voynow JA, Gendler SJ, and Rose MC. Regulation of Mucin Genes in Chronic Inflammatory Airway Disease. American Journal of Respiratory Cell and Molecular Biology. 2006; 34(6): 661-665.

16. Brody JS and Spira A. State of the Art. Chronic Obstructive Pulmonary Disease, Inflammation, and Lung Cancer. Proceedings of the American Thoracic Society. Boston, August 1, 2006; hal. 535-537.

17. Kumalaningsih S. Antioksidan Alami, Penangkal Radical Bebas, Sumber, Manfaat, Cara Penyediaan dan Pengolahan. Surabaya: Trubus Agrisarana; 2007; hal. 34-40, 53-57, dan 64-65.

18. Kun TD dan Sunarmani. 2008. Parameter Likopen dalam Standardisasi Konsentrat Buah Tomat. (Online) 2008. http:www.bsn.go.id/Files/@Lltbang [diakses tanggal 20 Maret 2010].

19. Di Mascio P, Kaiser S, and Sies H. Lycopene as the Most Efficient Biological Carotenoid Singlet Oxygen Quencher. Archieves of Biochemistry and Biophysics. 1989; 274(2): 532-538.

20. Wang JS, Tang L, Zeng X, and Jin T. Lycopene Inhibits the Growth of Human Androgen-Independent Prostate Cancer Cell In Vitro and in BALB/c Nude Mice. Journal of Nutrition. 2005; 135(2): 287-290.

21. Devaraj S, Mathur S, Basu A, et al. A Dose-Response Study on the Effects of Purified Lycopene Supplementation on Biomarkers of Oxidative Stress. Journal of the American College of Nutrition. 2008; 27(2): 267-273. 